\title{
The development of Study Program in Vocational Secondary School in Accordance with Main Economic Activity in Six Economic Corridors
}

\author{
S. Daryanto \\ Research Center, Office of Educational \\ Research and Development, Ministry of \\ Education and Culture \\ South Jakarta, Indonesia \\ siswantariarin@gmail.com
}

\begin{abstract}
The purpose of this study was to analyze the expertise study program that need to be held in Vocational Secondary School and to find the development pattern of expertise competency in provincial level and/or expertise study program and expertise competency in the district/city level appropriate with its Main Economic Activities. The study used primary and secondary data. Primary data was the expertise study program needed to develop 20 main economic activities, collected by discussion with association in Main Economic Activities. Secondary data was the expertise study program conducted in $\mathbf{1 3}$ sample provinces, collected using questionnaires with respondent the Head of Secondary Education Division in Provincial Education Offices. This study concluded that expertise study program conducted in the provinces were not yet appropriate with its Main Economic Activities. Analysis in this study can be applied to consider opening expertise competency in the provincial level and/or expertise study program and expertise competency in district/city level.
\end{abstract}

Keywords- Vocational Secondary School, Expertise Study Program, Expertise Competency, Economic Corridor, Main Economic Activity.

\section{INTRODUCTION}

National Medium-Term Development Plan 2010-2014 stated there are some efforts to improve the alignment of education and the work world, two of them are (i) increasing the quality and relevance of secondary vocational education to produce graduates ready to enter the work world and have entrepreneurial ethos through harmonization of vocational secondary education in order to respond to the needs of a dynamic market; and (ii) development of both national and local curriculum adapted to the development of science, technology, culture and art as well as global, regional, national, and local kinesthetic including the development and integration of life skills education to improve the work ethic and entrepreneurial abilities of learners (Permendikbud No. 44 tahun 2010).

Vocational High School (SMK) required always to improve its relevance to the business/industrial world, as well as can support economic growth in the district/city or province
SMK location. Therefore, SMK supposedly able to produce graduates who are ready to work to meet the needs of business/industrial world. At least for business/industrial world in the district/city or graduates can work independently. In order for vocational school graduates are ready to work, their competencies must be in accordance with the competencies needed by business/industrial world. The more quality of vocational school graduates, the smaller the competence gap of its graduates with that needed by business/industrial world, thus more easily absorbed by the labor market (Yoesoef and Muawanah, 2007).

Success as become workers in the labor market means creating revenue. SMK graduates absorption into the labor market means the creation of revenue for vocational school graduates, as well as revenue for the region (in the form of Gross Domestic Product /GDP). Therefore, the implementation and development of study programs should be in harmony with the local/regional potential where SMK location, with the hope of all graduates can be absorbed in the local/regional business/industrial world.

One graduate absorption indicator in business/industrial world is the level of unemployment, which causes include various things in between is graduate low competence and graduate study programs incompatibility to those required in accordance with the region potential. BPS data (2013) shows that the open unemployment rate of vocational school graduates tend to increase, especially in the last three years. Data from the years 2007 - 2013 (see Table 1) shows that from 2007 to 2011 the number of unemployment continues to decline and from 2011 to 2013 increased steadily, even 2012 to 2013 increased sharply.

TABLE 1. TOTAL UNEMPLOYMENT OF VOCATIONAL SCHOOL GRADUATES IN THE YEAR 2007-2013

\begin{tabular}{lll}
\hline Year & Total Unemployment (people) & Changes (percent) \\
\hline 2007 & 1.538 .349
\end{tabular}




$\begin{array}{lll}2008 & 1.409 .128 & \text { Down } 9.17 \\ 2009 & 1.407 .22 & \text { Down } 0.14 \\ 2010 & 1.195 .192 & \text { Down } 17.74 \\ 2011 & 1.032 .317 & \text { Down } 15.78 \\ 2012 & 1.041 .265 & \text { Up } 0.86 \\ 2013 & 1.259 .444 & \text { Up } 17.32\end{array}$

Source: Badan Pusat Statistik, 2013

Thus efforts to develop expertise in vocational courses has such an important role in efforts to reduce the number of open unemployment vocational graduates.

Development direction of study programs in SMK is in line with national development vision as stated in Law No. 17 Year 2007 on the National Long-Term Development Plan 20052025. National development vision is directed to master plan for the acceleration and expansion of Indonesia 's economic development (in Indonesian is MP3EI) to "Creating an Independent, advanced, Fair and Prosperous Indonesian Community " that will be realized through 3 (three) mission became the main focus, namely: (i) increase value added and the expansion of the value chain of the production process as well as the distribution of assets and access management (potential) natural resources, geographic region, and human resources, through the creation of an integrated economic activity and synergy within and inter-regional economic growth centers; (ii) promote the realization of an increase production and marketing efficiency as well as the integration of the domestic market in order to strengthen the competitiveness and resilience of the national economy; and (iii) to encourage the strengthening of the national innovation system in terms of production, process, and marketing to strengthen the sustainable global competitiveness of, towards innovation-driven economy.

To implement the third mission, the Indonesian Government launched MP3EI which is positioning Indonesia into industrialized country in 2025. One of the main strategies in the implementation of MP3EI is to increase the economic potential of the region through economic corridors (EC) which consists of six EC. This means that each region develop a product that becomes its superiority. Each EC advantages different depending on its potential natural resources and each EC have a theme. For example, EC I is the Sumatra island which has six Main Economic Activity (MEA) comprising (i) palm; (ii) rubber; (iii) coal; (iv) shipping; (v) steel; and (vi) Strategic National Region of Sunda Strait.

In order to increase the region economic potential, the education role of human resources is the key factor in supporting sustainable economic growth. It is necessary for the education and training system can create human resources who able to adapt quickly to the development of science and technology. One human resource capabilities needed is middle level educated and skilled to operate and take advantage of high-tech machinery and equipment. SMK graduates are categorized as middle level educated and skill, thus are expected to participate in the implementation of MP3EI projects as well as empowerment activity.

Since MP3EI was launched in May 2011, mapping gap analysis of study programs conducted in SMK with study programs required for the development of MP3EI at the provincial level has never been done. So that, it is important to conduct this study to answer the relevance problem of the workforce preparation to the needs of the business/industrial world and regional development

The purpose of this study are (i) to analyze the study programs that needs to be opened the province as an effort to develop MEA while reducing the unemployment level, and (ii) to find a development pattern of study program dan skill competency in province and district/city level in accordance with its MEA.

\section{LITERATURE REVIEW}

Expertise in SMK. According to Cohen (2011), the notion of expertise is in depth knowledge or proficiency in something. Expertise can cover a variety of fields, for example, marketing, warfare, management, stock management and so on. Expertise can also be in terms of what to eat, how to walk, or even the best way to do a job. Expertise can be anything that humans do (Cohen, 2011). Meanwhile, according to the real sense, competency are the advantages possessed by someone. Competence born of a long learning process, must be dug and found not granted. Skill competency can be defined as a deep knowledge or proficiency in the advantage matters of a person from a long learning process. Competence is a competitive advantage key to face the increasingly fierce market competition (Kiyosaki 2006).

Expertise in SMK used Spectrum and stated in the decision of the Director General of Primary and Secondary Education Ministry of National Education No. 251/C/KEP/MN/2008 on Expertise'Spectrum for Vocational Secondary Education. That Spectrum used the term field of study, study and skill competency. Field of study was group or expertise clumps in SMK. Expertises in SMK were grouped into six fields of study:(i) Technology and Engineering, (ii) Information and Communication Technology, (iii ) Health, (iv) Arts, Crafts and Tourism, (v) Agribusiness and Agro technology, and (vi) Business and Management.

The study program was department in a field of study, while skill competence was specialized in a study program. Field of study Technology and Engineering studies was divided into 18 study programs and broken down into 66 skill competencies. Summary of the spectrum can be seen in Table 2 .

TABLE 2. SPECTRUM SUMMARY OF SMK EDUCATION

\begin{tabular}{|c|c|c|c|}
\hline Number & Fiedd of Study & $\begin{array}{c}\text { Number of Study } \\
\text { Progtam }\end{array}$ & $\begin{array}{l}\text { Number of Skill } \\
\text { Competency }\end{array}$ \\
\hline T. & Technology and Enginering & 18 & 66 \\
\hline 2. & Information and Commmication Technology & 3 & 9 \\
\hline 3. & Health & 2 & 6 \\
\hline 4. & Arts, Crafts and Tourism & 7 & 22 \\
\hline 5. & Agribusiness and Agro Technology & 7 & 14 \\
\hline \multirow[t]{2}{*}{6.} & Business and Management & 3 & 4 \\
\hline & Total & 40 & 121 \\
\hline
\end{tabular}

Source : Directorate General Dikdasmen, 2008 


\section{A. Indonesia EC development}

MP3EI development was breakthrough approach with three main strategies that the two of them were the EC development and capability strengthening of human resources as well as national science and technology. Within the framework of human resource capacity strengthening that was to strengthen the middle-level personnel among them was SMK ( MP3EI , 2011).

The division of Indonesian into six EC was based on superiority, strategic potential and geo-strategic position of each region. Each EC had a theme and its advantages. Overall there were 22 kinds of superiority as shown in Table 3. Java EC had the highest number of MEA that were seven kinds and Bali-Nusa Tenggara EC with MEA least number, a total of three kinds.

TABLE 3. MEA DISTRIBUTION IN SIX ECONOMIC CORRIDORS

\begin{tabular}{|c|c|c|c|c|c|c|c|}
\hline$\overline{\text { Economics }}$ & & & & Economics A & chintiles & & \\
\hline Comdor" & (l) & (2) & $(3)$ & (4) & (5) & (0) & (1) \\
\hline Sumatera & plam & Rubber & cod & shipping & inon & $\begin{array}{c}\text { Stategicic } \\
\text { Sational Reggion }\end{array}$ & \\
\hline Java & Textle & $\begin{array}{l}\text { Food and } \\
\text { beverage }\end{array}$ & $\begin{array}{l}\text { Iranspotata- } \\
\text { tion } \\
\text { equipment }\end{array}$ & Telematics & $\begin{array}{l}\text { The main } \\
\text { means of } \\
\text { defense } \\
\text { systems }\end{array}$ & shipping & $\begin{array}{l}\text { Jabode } \\
\text { tabeek } \\
\text { area }\end{array}$ \\
\hline Kadimantan & palm & Timber" & $\begin{array}{l}\text { Olland } \\
\text { Gas }\end{array}$ & Steel & Baulute & cod & \\
\hline Sularies! & $\begin{array}{l}\text { Agricul: } \\
\text { ture }\end{array}$ & Cocos & Fisshenes & Nickel & $\begin{array}{l}\text { Oil and } \\
\text { Gass }\end{array}$ & & \\
\hline $\begin{array}{l}\text { Badi:Vlusa } \\
\text { Tengegala }\end{array}$ & Tounsm & livestodk & Fishanes & & & & \\
\hline $\begin{array}{l}\text { Pappla-Kepulauan } \\
\text { Malukn }\end{array}$ & $\begin{array}{l}\text { Agnicul- } \\
\text { ture } \\
\text { ture }\end{array}$ & Fishenes & Mining & Nickel & $\begin{array}{l}\text { Oiland } \\
\text { Gas }\end{array}$ & & \\
\hline
\end{tabular}

\section{B. Previous research results}

According to Evan and Edwin (1978), vocational education is part of the education system that prepares individuals to perform a job or group of jobs. House Committee on Education and Labour (HCEL) defines vocational education as a form of talent development, and the habits that lead to the work world and training is seen as a skill (Malik, 1990). Of the two understanding, there are at least two focuses sides which are the institution of education/training and the work world. Sudira (2014), stated that vocational education is progressive economic education. Vocational education is progressive means to be able to educate and train students to produce and deliver adaptive services to the occurrence changes. Furthermore Sudira stated that as a progressive economic education, vocational education is measured and assessed its effectiveness and efficiency socially in human resources development to support economic development. Thus vocational education institutions are effective and efficient if they are able to produce graduates who are productive and able to support economic development, which includes business/industrial world development and regional economic development.

As a vocational institution that producing graduates who are likely to be a mid-level skilled workers in the business/industrial world, SMK is expected to support region economic growth. That's in line with a statement Yoesoef et al. ( in Aini 2010), SMK " Industry" has positive role in regional economic growth. Public interest against SMK related to the SMK development which related to its quality graduates. These graduates quality can be decisive in the labor market, and in turn, become a contributor to regional economic growth

Thus SMK is required to always improve its graduates quality, in line with the effort to increase its relevance to the work world. The low level relevance can result in lower graduate employment by the work world. Efforts to develop relevance between SMK with business/industrial world can be done in various ways. One way is to operate study programs appropriate to those the work world demand.

On the other hand, business/industrial world need to be built or developed in an area in accordance with the regional potential, in MP3EI context is mentioned as MEA. Thus the study programs in SMK need to be developed in accordance with the potential of SMK location. But the study of Premono (2010) in Tangerang City stated that the development of the new SMK was not based on the regional potential. Although this study related to the area potential, but nothing to do with MP3EI and did not map study program as this study. This is in line with the research result of Aini (2010) in Sidoarjo which revealed that SMK only provide study programs which less value-added advantages for students after graduation and graduates (Industrial Technology study program) less support existing industrial potential.

Furthermore, Aini (2010) stated SMK development towards certain economy potential need further studies on aspects related to the industrial potential so that study programs development completely in accordance with the society needs.

Based on the research was concluded that SMK study programs organized generally not in accordance with local/ potential advantages and regional so that had not provide significant contributions to the economic growth and may result in poor employment of SMK graduates in the region. Thus efforts to develop study programs relevant to area potential need to be done.

\section{METHOD}

This research was conducted in 2013. The province sample was selected purposively that is active in the opinion of the Person In Charge (PIC) for each EC, as shown in Table 4. The PIC is a certain ministry officials were given the authority to coordinate the various activities in the EC region as his working area. (MP3EI, 2011). 
TABLE 4. THE SAMPLE IN EACH PROVINCE AND THE PIC MINISTRY

\begin{tabular}{|c|c|c|c|}
\hline $\begin{array}{l}\text { Economics Corridor } \\
\text { (EC) Number }\end{array}$ & CE Region & PIC Ministry & Sample Provincies \\
\hline 年 & Sumatera & Forestry & $\begin{array}{l}\text { 1. North Sumatera } \\
\text { 2. South Sumatera } \\
\text { 3. Lampung }\end{array}$ \\
\hline II. & Java & Public Works & $\begin{array}{l}\text { 1. West Java } \\
\text { 2. Central Java } \\
\text { 3. East Java }\end{array}$ \\
\hline III. & Kalimantan & Agricultural & $\begin{array}{l}\text { 4. West Kalimantan } \\
\text { 5. South Kalimantan }\end{array}$ \\
\hline IV. & Sulawesi & $\begin{array}{l}\text { Maritime Affairs } \\
\text { and Fisheries }\end{array}$ & $\begin{array}{l}\text { 6. Central Sulawesi } \\
\text { 7. Sulawesi Selatan }\end{array}$ \\
\hline $\mathrm{v}$. & $\begin{array}{l}\text { Bali - Nusa } \\
\text { Tenggara }\end{array}$ & $\begin{array}{l}\text { Tourism and } \\
\text { Creative Economy }\end{array}$ & $\begin{array}{l}\text { 8. West Nusa Tenggara } \\
\text { 9. East Nusa Tenggara }\end{array}$ \\
\hline VI. & Papua - Maluku & Transportation & 10. Maluku \\
\hline
\end{tabular}

Primary data was collected in Jakarta through discussions with several MEA associations and engineering faculty lecturers of Jakarta State University. Primary data, especially in the study programs needed for the MEA development thoroughly. Those study programs are needed to execute MP3EI projects in the upstream and downstream industries which includes consumption, clothing, health, safety and comfort.

Secondary data were collected in 13 provinces, those were study programs conducted at the provincial level in 2013, through respondent the Head of Secondary Education Department, in Provincial Education Office. Data analysis was done by mapping study programs organized in provincial level and those required for the development of MP3EI.

\section{RESULTS}

\section{A. Study Programs Needed to be Opened in six EC Sumatra EC}

The study programs required and were not yet available, so that to be opened ranging from three to ten (see Table 5). The study program most needed, namely ten, there were in three field of study found in South Sumatra and Lampung, respectively for the development of palm and rubber.

\section{TABLE 5. STUDY PROGRAMS NEED TO BE OPENED IN THREE} PROVINCES IN SUMATRA EC

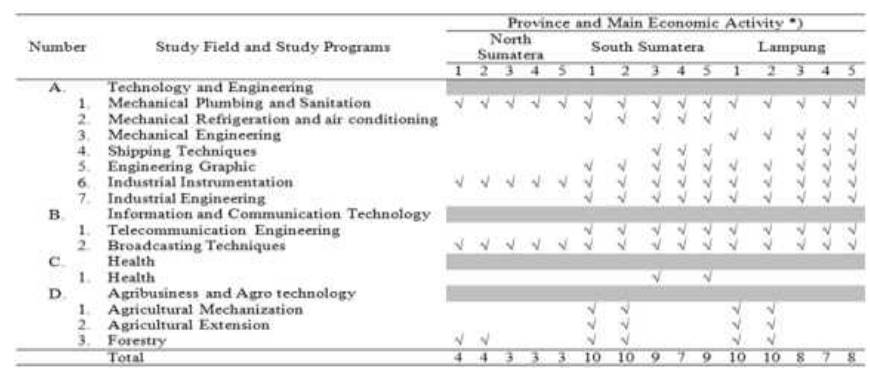

*) Note: 1: palm; 2: rubber; 3: coal; 4: shipbuilding; 5: steel

The least number of required study programs was in North Sumatra, which includes of three study programs. The three study programs need to be opened in three provinces, but not yet available.

\section{B. Java EC}

Table 6 shows study programs needed for the MEA development in Java. The program study number ranging from one to four. The four study program were needed in East Java in field of study of Technology and Engineering, respectively for the development of the food and beverage industry, as well as transportation equipment.

TABLE 6. STUDY PROGRAMS NEED TO BE OPENED IN THREE PROVINCES IN JAVA EC

\begin{tabular}{|c|c|c|}
\hline \multirow[t]{3}{*}{ Number } & \multirow{3}{*}{$\begin{array}{l}\text { Study Field and } \\
\text { Study Programs }\end{array}$} & Province and Main Economic Activity ${ }^{*}$ ) \\
\hline & & West Java Central Java \\
\hline & & 12334566123345661234456 \\
\hline \multicolumn{3}{|l|}{ A. } \\
\hline 1 . & Mechanical Plumbing and Sanitation & $\sqrt{ } \sqrt{ } \sqrt{ }$ \\
\hline 2. & Graphic Techniques & $\sqrt{ } \sqrt[j]{ } \sqrt[j]{ }$ \\
\hline 3. & Industrial Instrumentation & $\sqrt{ } \sqrt{ } \sqrt{ } \sqrt{ } \sqrt{ } \sqrt{ } \sqrt{ } \sqrt{ }$ \\
\hline \multirow{2}{*}{$\begin{array}{l}4 . \\
5\end{array}$} & Industrial Engineering & $\sqrt[j]{ } \sqrt[j]{ }$ \\
\hline & Shipping Techniques & $\sqrt{j}$ \\
\hline 5. & Total & 133333213334442332 \\
\hline
\end{tabular}

*)Description; 1: textiles; 2: food and beverages; 3: transportation equipment; 4: telematics; 5 : alutista 6:shipbuilding

The least number of study programs needed to be opened was in West Java, only Mechanical Plumbing and Sanitation, which was required for industrial development (i) Textiles, (ii) Food and Beverage, (iii) Transport Equipment and (iv) Shipping. The overall program study needed to be opened in three provinces were five all are in Technology and Engineering field of study. Mechanical Plumbing and Sanitation study program needed to be opened in these three provinces. The analysis showed that study programs have been developed in Java tend to be more in line with the need to manage the region potency, compared with Sumatra.

\section{Kalimantan EC}

Three natural resources on Kalimantan were the same as Sumatera natural potential, namely palm, steel and coal. Table 7 showed the study programs needed to be opened in Kalimantan. The number of study programs required ranging from $5-10$. Ten study programs needed to be opened in West Kalimantan, covering the development of four MEA consists of oil and gas, steel, bauxite and coal.

\section{TABLE 7. STUDY PROGRAMS NEED TO BE OPENED IN TWO} PROVINCES IN KALIMANTAN EC

\begin{tabular}{|c|c|c|c|c|c|c|c|c|c|c|c|c|}
\hline \multirow[t]{3}{*}{ Number } & \multirow[t]{3}{*}{ Study Field and Study Programs } & \multicolumn{11}{|c|}{ Province and Main Economic Activity *) } \\
\hline & & \multicolumn{6}{|c|}{ West Kalimantan } & \multicolumn{5}{|c|}{ South Kalimantan } \\
\hline & & 1 & & 3 & 4 & 5 & 6 & & 23 & 34 & 5 & 6 \\
\hline A. & Technology and Engineering & & & & & & & & & & & \\
\hline 1. & Mechanical Plumbing and Sanitation & $\sqrt{ }$ & $\sqrt{ }$ & $\sqrt{ }$ & $\sqrt{ }$ & $\sqrt{ }$ & $\sqrt{ }$ & $\sqrt{ }$ & 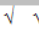 & $\sqrt{ } \sqrt{ }$ & $\sqrt{ }$ & $\sqrt{ }$ \\
\hline 2. & Shipping Techniques & & & $\sqrt{ }$ & $\sqrt{ }$ & $\sqrt{ }$ & $\sqrt{ }$ & & & & & \\
\hline 3. & Graphic Techniques & $\sqrt{ }$ & & $\sqrt{ }$ & $\sqrt{ }$ & $\sqrt{ }$ & $\sqrt{ }$ & & & & & \\
\hline 4. & Mining Geology & & & $\sqrt{ }$ & $\sqrt{ }$ & $\sqrt{ }$ & $\sqrt{ }$ & & & & & \\
\hline 5. & Industrial Instrumentation & $\sqrt{ }$ & $\sqrt{ }$, & $\sqrt{ }$ & $\sqrt{ }$ & $\sqrt{ }$ & $\sqrt{ }$ & $\sqrt{ }$ & & $\sqrt{ } \sqrt{ }$ & & \\
\hline 6. & Chemical Engineering & $\sqrt{ }$ & $\sqrt{ }$ & $\sqrt{ }$ & $\sqrt{ }$ & $\sqrt{ }$ & $\sqrt{ }$ & $\sqrt{ }$ & & $\sqrt{ } \sqrt{ }$ & $\sqrt{ }$ & $\sqrt{ }$ \\
\hline 7. & Industrial Engineering & $\sqrt{ }$ & $\sqrt{ }$ & $\sqrt{ }$ & $\sqrt{ }$ & $\sqrt{ }$ & $\sqrt{ }$ & $\sqrt{ }$ & $\sqrt{ }$ & $\sqrt{ } \sqrt{ }$ & $\sqrt{ }$ & $\sqrt{ }$ \\
\hline B. & Information and Communication Technology & & & & & & & & & & & \\
\hline 1. & Telecommunication Engi & $\sqrt{ }$ & $\sqrt{ }$ & v & $\sqrt{ }$ & $\sqrt{ }$ & $\sqrt{ }$ & & & & & \\
\hline C. & Health & & & & & & & & & & & \\
\hline 1. & Health & & . & V & $\sqrt{ }$ & $\sqrt{ }$ & $\sqrt{ }$ & & & & & \\
\hline E. & Agribusiness and Agro technology & & & & & & & & & & & \\
\hline 1. & Agricultural Mechanization & $\sqrt{ }$ & $\sqrt{ }$ & & & & & $\sqrt{ }$ & $\sqrt{ }$ & & & \\
\hline 2. & Agricultural Extension & & & & & & & $\sqrt{ }$ & $\sqrt{ }$ & & & \\
\hline 3. & Forestry & $\sqrt{ }$ & $\sqrt{ }$ & $\mathrm{v}$ & $\sqrt{ }$ & $\sqrt{ }$ & $\sqrt{ }$ & $\sqrt{ }$ & $\sqrt{ }$ & $\sqrt{ } \sqrt{ }$ & $\sqrt{ }$ & $\sqrt{ }$ \\
\hline tal & & 8 & 81 & 0 & 10 & 10 & 10 & 7 & 75 & 55 & 5 & 5 \\
\hline
\end{tabular}

*) Note: 1: palm; 2: timber; 3 oil and gas; 4: steel; 5: bauxite; and 6: coal. 


\section{Sulawesi EC}

Agriculture as MEA in EC IV was more focused on food agriculture commodity include rice, corn and soybeans. One of Sulawesi natural potential was the same as that in Kalimantan, namely oil and gas. Table 8 showed the study programs needed to be opened in Sulawesi EC.

\section{TABLE 8. STUDY PROGRAMS NEED TO BE OPENED IN TWO} PROVINCES IN SULAWESIEC

\begin{tabular}{|c|c|c|c|c|c|c|c|c|c|c|c|c|}
\hline \multirow{3}{*}{ Number } & \multirow{3}{*}{ Study Field and Study Programs } & \multicolumn{11}{|c|}{ Province and Main Economic Activity *) } \\
\hline & & \multicolumn{5}{|c|}{ Central Sulawesi } & \multicolumn{6}{|c|}{ South Sulawesi } \\
\hline & & 1 & 2 & 3 & 4 & 5 & 1 & 2 & 3 & & & 5 \\
\hline \multicolumn{13}{|c|}{ A. Teknologi dan Rekayasa } \\
\hline 1. & Plambing dan Sanitary Engineering & $\sqrt{ }$ & $\sqrt{ }$ & $\sqrt{ }$ & $\sqrt{ }$ & $\sqrt{ }$ & $\sqrt{ }$ & $\sqrt{ }$ & $\sqrt{ }$ & & & $\sqrt{ }$ \\
\hline 2. & Mechanical Refrigeration and air conditioning & $\sqrt{ }$ & $\sqrt{ }$ & $\sqrt{ }$ & $\sqrt{ }$ & $\sqrt{ }$ & & & & & & $\sqrt{ }$ \\
\hline 3. & Shipping Techniques & & & & $\sqrt{ }$ & $\sqrt{ }$ & & & & & & \\
\hline 4. & Graphics Techniques & $\sqrt{ }$ & $\sqrt{ }$ & $\sqrt{ }$ & $\sqrt{ }$ & $\sqrt{ }$ & & & & & & \\
\hline 5. & Industrial Instrumentation & $\sqrt{ }$ & $\sqrt{ }$ & $\sqrt{ }$ & $\sqrt{ }$ & $\sqrt{ }$ & & & & & & \\
\hline 6. & Chemical Engineering & $\sqrt{ }$ & $\sqrt{ }$ & $\sqrt{ }$ & $\sqrt{ }$ & $\sqrt{ }$ & & & & & & \\
\hline \multicolumn{11}{|c|}{ Information and Communication Technology } & & \\
\hline 1. & Broadcasting Techniques & & & & & & $\sqrt{ }$ & $\sqrt{ }$ & $\sqrt{ }$ & & & $\sqrt{ }$ \\
\hline C. & Health & & & & & & & & & & & \\
\hline 1. & Health & & & & & & & & $\sqrt{ }$ & & & $\sqrt{ }$ \\
\hline \multicolumn{13}{|c|}{ E. Agribusiness and Agro technology } \\
\hline 1. & Agricultural Mechanization & & & & & & $\sqrt{ }$ & $\sqrt{ }$ & & & & \\
\hline 2. & Agricultural Extension & $\sqrt{ }$ & $\sqrt{ }$ & $\sqrt{ }$ & & & & & & & & \\
\hline \multicolumn{2}{|c|}{ 3. Forestry } & $\sqrt{ }$ & $\sqrt{ }$ & $\sqrt{ }$ & $\sqrt{ }$ & $\sqrt{ }$ & $\sqrt{ }$ & $\sqrt{ }$ & $\sqrt{ }$ & & & \\
\hline & Total & 7 & 7 & 7 & 7 & 7 & 4 & 4 & 4 & & & 4 \\
\hline
\end{tabular}

*) Note: 1: agriculture; 2: cocoa; 3: fisheries; 4: Nickel; 5: oil and gas.

To manage the Sulawesi natural potential, three to seven study programs needed to be opened. Seven study programs needed to be opened in Central Sulawesi, for all MEA. The least study programs number needed to be opened was three, happened in South Sulawesi needed for the development of nickel. The overall study program needed to be opened in South Sulawesi and Central Sulawesi as much as 11. Among the eleven study programs, respectively, six were in Technology and Engineering field of study, one each in field of Information and Communication Technology as well as Health and three in Agribusiness and Agro Technology field of study. Mechanical Plumbing and Sanitation expertise needed to be held either in Central Sulawesi and South Sulawesi for development of five MEA.

\section{E. Bali-Nusa Tenggara EC}

Table 9 showed study programs required for the MEA development but not yet available in West Nusa Tenggara dan East Nusa Tenggara. The number of study programs required expertise ranging four to nine. The greatest study program number was happened in West Nusa Tenggara, for tourism and animal husbandry development. Among the nine, seven study programs for animal husbandry development were also needed for tourism development. Two study programs which only for animal husbandry development were Industrial Instrumentation and Agricultural Mechanization.

TABLE 9. STUDY PROGRAMS NEED TO BE OPENED IN TWO PROVINCES IN BALI-NUSA TENGGARA EC

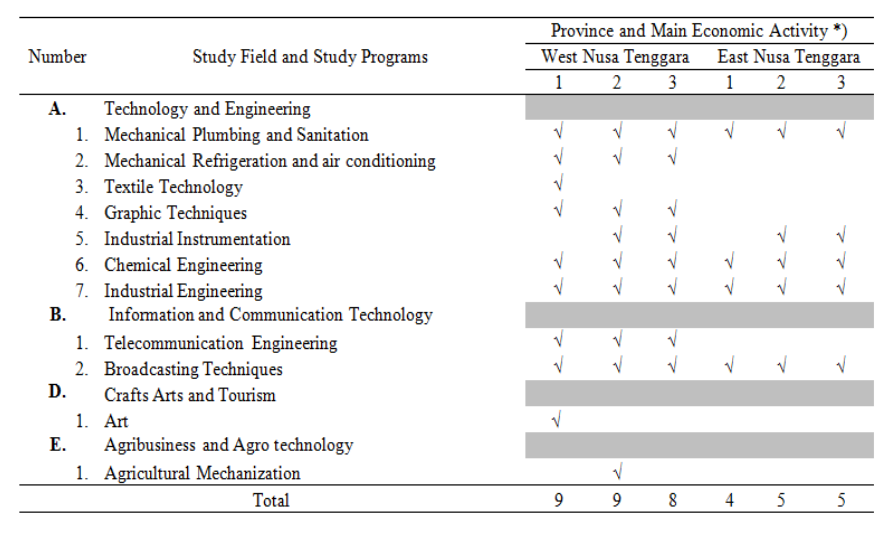

*) Description; 1: tourism; 2: livestock; 3: fisheries

The least study program number needed to be opened in Nusa Tenggara was four, all for tourism development. All study programs needed to be opened in Bali-Nusa Tenggara CE but not yet available in two provinces was 11. Among the eleven study programs, seven were Technology and Engineering, two in Information and Communication Technology, one each in the Crafts Arts and Tourism as well as Agribusiness and Agro Technology.

\section{F. Рapua-Maluku EC}

The study program needed to be opened in Maluku could be seen in Table 10. The study program number needed to be opened for MEA development was ranging seven to nine. The highest study program number was nine, for the development of agriculture. Nine study programs as well needed to be opened for copper, nickel as well as oil and gas development. There were seven study programs needed to be opened for fishery development.

TABLE 10. STUDY PROGRAMS NEED TO BE OPENED IN MALUKU IN PAPUA-MALUKU EC

\begin{tabular}{|c|c|c|c|c|c|c|}
\hline \multirow{3}{*}{ Number } & \multirow{3}{*}{ Field of Study and Study Programs } & \multicolumn{5}{|c|}{ Province and Main Economic Activity *) } \\
\hline & & \multicolumn{5}{|c|}{ Maluku } \\
\hline & & 1 & 2 & 3 & 4 & 5 \\
\hline \multicolumn{7}{|c|}{ A. Technology and Engineering } \\
\hline 1. & Mechanical Plumbing and Sanitation & $\sqrt{ }$ & $\sqrt{ }$ & $\sqrt{ }$ & $\sqrt{ }$ & $\sqrt{ }$ \\
\hline & Technical Survey and Mapping & $\sqrt{ }$ & $\sqrt{ }$ & $\sqrt{ }$ & $\sqrt{ }$ & $\sqrt{ }$ \\
\hline & Air Conditioning and Refrigeration Engineering & $\sqrt{ }$ & $\sqrt{ }$ & $\sqrt{ }$ & $\sqrt{ }$ & $\sqrt{ }$ \\
\hline & Shipbuilding Techniques & & & $\sqrt{ }$ & $\sqrt{ }$ & $\sqrt{ }$ \\
\hline & Mining Geology & & & $\sqrt{ }$ & $\sqrt{ }$ & $\sqrt{ }$ \\
\hline & Industrial Instrumentation & $\sqrt{ }$ & $\sqrt{ }$ & $\sqrt{ }$ & $\sqrt{ }$ & $\sqrt{ }$ \\
\hline & Chemical Engineering & $\sqrt{ }$ & $\sqrt{ }$ & $\sqrt{ }$ & $\sqrt{ }$ & $\sqrt{ }$ \\
\hline \multicolumn{7}{|c|}{ B. Information and Communication Technology } \\
\hline & Telecommunication Engineering & $\sqrt{ }$ & $\sqrt{ }$ & $\sqrt{ }$ & $\sqrt{ }$ & $\sqrt{ }$ \\
\hline 2. & Broadcasting Techniques & $\sqrt{ }$ & $\sqrt{ }$ & $\sqrt{ }$ & $\sqrt{ }$ & $\sqrt{ }$ \\
\hline \multicolumn{7}{|c|}{ E. Agribusiness and Agro technology } \\
\hline 1. & Agricultural Mechanization & $\sqrt{ }$ & & & & \\
\hline \multicolumn{2}{|c|}{ 2. Forestry } & $\sqrt{ }$ & & & & \\
\hline & Total & 9 & 7 & 9 & 9 & 9 \\
\hline
\end{tabular}

*) Description; 1: agriculture; 2: fisheries; 3: Copper; 4: Nickel; 5: Oil and gas

The overall study program needed to be opened was 11 . Among 11, seven study programs were in Technology and Engineering, two each in Information and Communication Technology as well as Agribusiness and Agro-technology. Totally there were seven study programs for all MEA development di Maluku. 


\section{G. Development Pattern of Study Programs and Skill Competency}

Based on the analyzing experience, it is known that the analysis could be applied to develop skill competencies in provincial level as well as study programs and skill competencies ini district/city level. There were several steps needed to be taken. Steps to develop skill competencies at the provincial level, namely: (i) collect data on skill competencies existed in provincial level for a given year and mapping it; (ii) get the data on skill competencies needed to develop MEA through discussions with MEA associations; (iii) mapping that data; and (iv) mapping the gap skill competencies needed to develop MEA and skill competencies. The gap was skill competencies needed to be opened in the province concerned.

Steps to develop skill competencies at the district/city level, namely: (i) collect data on skill competencies existed in provincial level for a given year and mapping it; (ii) get the data on skill competencies needed to develop MEA through discussions with MEA associations; (iii) mapping the data got in point (ii) ; and (iv) mapping the gap skill competencies needed to develop MEA and skill competencies existed. The gap was skill competencies needed to be opened in the province concerned.

Steps to develop study programs at the district/city level, namely: (i) collect data on study programs existed in district/city level for a given year and mapping it; (ii) get the data on study programs needed to develop MEA through discussions with MEA associations; (iii) mapping the data got in point (ii); and (iv) mapping the gap study programs needed to develop MEA and study programs existed. The gap was study programs needed to be opened in the district/city concerned.

Steps to develop skill competencies at the district/city level, namely: (i) collect data on skill competencies existed in district/city level for a given year and mapping it; (ii) get the data on skill competencies needed to develop MEA through discussions with MEA associations; (iii) mapping the data got in point (ii); and (iv) mapping the gap skill competencies needed to develop MEA and skill competencies existed. The gap was skill competencies needed to be opened in the district/city concerned. It could happen, MEA district/city were not the same as the MEA EC, under such conditions MEA district/city needed to know first. Although MP3EI is no longer known in the current government, but "SMK development in accordance with the economic advantages of the region " that has been known since before the introduction MP3EI remain relevant to be implemented.

\section{CONCLUSIONS AND RECOMMENDATIONS}

\section{- CONCLUSION}

The study programs held in 13 provinces were not in accordance with the requirements for MEA development needed to be opened in SMK the province. The highest study program number need to be opened was 11, there were in South Sumatra, West Nusa Tenggara and Maluku. The lowest number was one only in West Java, namely Mechanical Plumbing and Sanitation. Mechanical Plumbing and Sanitation was categorized as rare study program, because all sample provinces had not have that study program. The analysis pattern to get study programs that relevant with the need of MEA EC could be applied to develop study programs in provincial level as well as study programs and skill competencies in district/city level.

\section{- RECOMMENDATION}

District /city governments need to follow program study development taking into account, among others: the natural potential or regional potential as well as superior product of the districts/cities, the society interest and to coordinate with the provincial education office. This is necessary because the opening authority of fields of study, study programs and skill competencies as well as new SMK is in the district/city level. Coordination with the provincial education office needed considering MP3EI programs tend to move "top down", from central government, provincial, and continues to district/city. Furthermore, the District/city Education Offices need to socialize to SMK and the public about the development of fields of study, study programs as well as skill competencies appropriate with local economic advantage. The society, especially parents of SMP/MTs/equal graduates need to know the various considerations related to the opening fields of study, study programs and skill competencies that may not follow the society trend. Lately, provincial education offices need to socialize the efforts to develop fields of study, study programs and skill competencies by considering the economic advantages of each region to the District/city Education Offices and called to follow up.

\section{REFERENCES}

[1] Aini, Q. 2010. Konsep Pengembangan Sekolah Menengah Kejuruan (SMK) Berbasis Industri Di Kabupaten Sidoarjo. Surabaya: Jurnal Penataan Ruang.

[2] Badan Pusat Statistik. Statistik Indonesia 2013. (http://www.bps.go.id, diunduh 23 Juni 2015)

[3] Cohen, William, A. 2011. Setiap Pemimpin Harus Baca Buku Ini: The New Art of The Leader. Jakarta: Tangga Pustaka.

[4] Evans, R. N. dan Edwin, L. H.1978. Foundation of Vocational Education. Columbus, OH: Charles E, Merril Publishing Company.

[5] Keputusan Direktur Jenderal Pendidikan Dasar dan Menengah Departemen Pendidikan Nasional Nomor:251/C/KEP/MN/2008 tentang Spektrum Keahlian Pendidikan Menengah Kejuruan.

[6] Kiyosaki, R.T. 2006. Strategi “menjual diri” Cara Gampang Dapat Kerjaan. Yogyakarta: Media Pressindo.

[7] Malik, Oemar H. 1990. Pendidikan Tenaga Kerja Nasional, Kejuruan Kewiraswastaan, dan Manajemen. Bandung: PT Citra Aditya Bhakti.

[8] Masterplan Percepatan dan Perluasan Pembangunan Ekonomi Indonesia (MP3EI)2011-

2025.(http://www.kp3ei.go.id/in/main_ind/content2/69/68,diunduh 130216)

[9] Peraturan Menteri Pendidikan Nasional Republik Indonesia Nomor 44 Tahun 2010 Tentang Perubahan Atas Peraturan Menteri Pendidikan Nasional Nomor 2 Tahun 2010 Tentang Rencana Strategis Kementerian $\begin{array}{lllll}\text { Pendidikan Nasional } & \text { Tahun } & 2010 \quad & - & 2014\end{array}$ (Http://Luk.Staff.Ugm.Ac.Id/Atur/Permen44-2010.Pdf , diunduh 18 Juni 2015)

[10] Premono, A. 2010. Kompetensi Keahlian Sekolah Menengah Kejuruan : Antara Kebijakan dan Realita. Jurnal Pendidikan Penabur, Nomor 15, Tahun ke-9, Desember 2010, 51- 61.

[11] Suradi, Putu. 2014. Konsep dan Praksis Pendidikan Hindu Berbasis Tri Hita Karana PS IHDN file://C:/data\%20pindahan/2015/RELEVANSI\%202015/BACAAN/LA 
PORAN-PENELITIAN-STRANAS-PUTU-UNY.pdf, diunduh 10 Juli 2015)

[12] Undang-Undang Nomor 17 Tahun 2007 tentang Rencana Pembangunan Jangka Panjang Nasional 2005-2025. (http://www.slideshare.net/perencanakota/undangundang-no-17-tahun2007-tentang-rencana-pembangunan-jangka-panjang-nasional-tahun2005-2025, diunduh 2 Februari 2013)
[13] Yoesoef, Jose R., Muawanah, Umi. 2007. Peran SMK dalam Menunjang Pertumbuhan Ekonomi Daerah; Sebuah Analisis Makroekonomika. URL:http://www.scribd.com/doc/23783304/Peran SMK dalam Menunjang Pertumbuhan EkonomiDaerah?secretpassword=autodown=pdf, diunduh 12 Februari 2010 . 